$N G 0-07-05$

\title{
LOCATIONS AND AREAS OF PONDS AND CAROLINA BAYS AT THE SAVANNAH RIVER PLANT
}

J. D. Shields, N. D. Woody, A. S. Dicks, G. J. Hollod,

J. Schalles, and G. J. Leversee

TIS FILE RECORD COPY

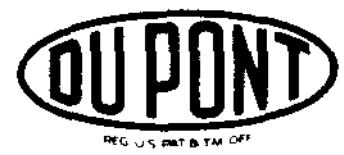

E. I. du Pont de Nemours \& Co. Savannah River Laboratory Aiken, SC 29808 


\section{DISCLAIMER}

This report was prepared as an account of work sponsored by the United States Government. Neither the United States nor the United States Department of Energy, nor any of their employees, make any warranty, express or implied, or assumes any legal liability or responsibility for the eccuracy, completeness, or usefulness of any information, apparatus, pro. duct, or process disclosed, or represents that its use would not infringe privately ovsned rights. Peference herein to any specific commercial pro. duct, procese, or service by trade neme, mark, manufacturer, or otherwise does not necessarily constitute or imply its endorsement, recommendation, or favoring by the United States Government or any agency thereof. The views and opinions of authors expressed herein do not necessarify state or reflect those of the United States Government or any agency thereof.

Printed in the United States of America

$$
\text { Available from }
$$

National Technical Information Service

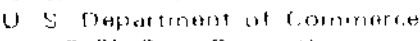

$5: 85$ Pal M Aoyal Huad

Sprugtield, Virgınta 22161

Price: Printed Copy A02; Miciofiche A01 


\section{LOCATIONS AND AREAS OF PONDS AND CAROLINA BAYS} AT THE SAVANNAH RIVER PLANT

by

J. D. Shields, N. D. Woody, A. S. Dicks, G. J. Hollod

E. I. du Pont de Nemours and Co., Savannah River Laboratory

and

J. Schalles, G. J. Leversee

University of Georgia, Savannah River Ecology Laboratory

Approved by

T. V. Crawford, Research Manager

Environmental Transport Division

Publication Date: June 1980

\section{Issued by E. 1. du Pont de Nemours \& Co. Savannah River Laboratory Aiken, SC 29808}


The Savannah River Plant has 28 ponds and 189 Carolina Bays on its 192,000-acre site. Excluding the Par Pond system, the mean pond area is 17.6 acres, with a range of 0.4 to 202.8 acres. par Pond is the largest pond, with an area of 2,500 acres. The mean Carolina Bay area is 6.6 acres, with a range of less than 0.3 to 124.0 acres. The geographical location of each pond and bay has been digitized and can be graphically displayed by computer. This capability will facilitate identification of wetland areas as required by Executive Order 11990 (Protection of Wetlands, May 24, 1977). 


$\begin{array}{lc} & \text { Page } \\ \text { Introduction } & 4 \\ \text { Detection and Measurement of Ponds and Bays } & 5 \\ \text { Results } & 5 \\ \text { References } & 6 \\ \text { Acknowledgment } & 6\end{array}$

\section{LIST OF TABLES}

Page

1 Areas and Locations of Ponds at SRP

2 Areas and Locations of Carolina Bays at SRP

1 Carolina Bays on the Savannah River Plant Reservation

2 Carolina Bays on the Northeast Quadrant of the Savannah River Plant Reservation

3 Carolina Bays on the Northwest Quadrant of the Savannah River Plant Reservation

4 Carolina Bays on the Southwest Quadrant of the Savannah River Plant Reservation

5 Carolina Bays on the Southeast Quadrant of the Savannah River Plant Reservation

6 Ponds on the Savannah River Plant Reservation 18

7 Size Distribution of Carolina Bays at SRP 


\section{INTRODUCTION}

Executive Order 11990 (Protection of Wetlands, May 24, 1977) requires that each Federal agency provide leadership and take action to minimize the destruction, loss, or degradation of wetlands. Federal agencies shall also take action to preserve and enhance the natural and beneficial values of wetlands by (1) acquiring, managing, and disposing of Federal lands and facilities; (2) providing federally undertaken, financed, or assisted construction and improvements; and (3) conducting federal activities and programs affecting land use, including but not limited to water and related land resources planning, regulating, and licensing activities.

The U.S. Department of Energy's Savannah River Plant (SRP), a 192,000-acre site near Aiken, South Carolina, is required to comply with Executive Order 11990. SRP's program to comply with the Order includes: (1) location and categorization of wetlands at SRP; (2) identification of site activities that affect these systems; (3) identification of 1iterature pertinent to SRP wetlands; (4) study of the response of aquatic systems to routine releases from SRP operations; and (5) suggested site action programs to increase emphasis on wetlands preservation. This document reporting the categorization and location of SRP ponds and Carolina Bays is a contribution to the first part of the program.

This report summarizes the locations and areas of a11 ponds and Carolina Bays on the Savannah River Plant Reservation. The ponds are defined as a body of water formed by the blockage or obstruction of the natural drainage pattern of streams. ${ }^{2}$ They can be either natural or manmade, and they include farm ponds, oxbows, and ponds caused by beaver dams. Carolina Bays are elliptical depressions that are usually oriented in the northwest-southeast direction, with no apparent inlet or outlet. ${ }^{3}$ The long axes of the bays range from a few hundred feet to a thousand feet in length. The bays are generally shallow and sometimes contain no standing water. "Suspect bays" are also included in this summary. These are bays that have been identified by aerial photographs as having the characteristics of Carolina Bays, although they have not as yet been documented by field studies. 


\section{DETECTION AND MEASUREMENT OF PONDS AND BAYS}

Depressions at the SRP site were located by examining a set of infra-red aerial photographs taken in March, 1978. A11 of the ponds and bays were then located on a topographic map of the Savannah River Plant using the Plant Grid System (Tables 1 and 2). The north and east plant grid coordinates for each pond and bay were then entered into the JOSHUA Computer Site Mapping Program for a graphical presentation.

The approximate area of each depression was determined with an Ott polar planimeter from the infra-red aerial photographs. The photographs had been taken normal to the surface, and their scale was $1: 15,840$. A comparison of the planimeter measurements with the accepted size of engineered ponds ${ }^{4}$ showed planimetry accuracy decreased as the size of the pond decreased. The relative precision of the area measurements of the Carolina Bays varied, with a precision of about $5 \%$ for the larger bays. The detection limit was 0.3 acre.

\section{RESULTS}

This study revealed 28 ponds and 189 Carolina Bays on the SRP site. The mean pond area is 17.6 acres when Par Pond is not included, with a range of 0.4 to 202.8 acres. Par Pond is the largest pond, with an area of 2,500 acres. The mean Carolina Bay area is 6.6 acres, with a range of less than 0.3 to 124.0 acres. Areas and locations are shown in Table 1 for ponds and in Table 2 for bays.

All Carolina Bays do not hold water, but the presence of aquatic vegetation, such as marsh grass and cattails, indicates higher soil moisture content compared to surrounding forest or grassland areas. The water depth in any Carolina Bay depends on seasonal variations in precipitation.

The north and east plant grid coordinates for each pond and bay, which are stored in the JOSHUA Computer System, allow for convenient display by computer graphics. Sample maps are shown in Figures 1 to 6 . The size distribution for the Carolina Bays is shown in Figure 7. 
1. U.S. Department of Energy. Floodplain Management and Protection of Wetlands. Federal Register, July 19, 1978 (Part III), page 31108.

2. T. M. Langley and W. L. Marter. The Savannah River Plant Site. USAEC Report DP-1323, E. I. du Pont de Nemours and Co., Savannah River Laboratory, Aiken, SC (1973).

3. Geologic-Engineering Investigation, Savannah River Plant. Conducted for the Atomic Energy Commission and E. I. du Pont de Nemours and Company by Charleston District Corps of Engineers, U.S. Army. Published in two volumes by Waterways Experiment Station, Corps of Engineers, U.S. Army, Vicksburg, Mississippi (March 1952).

4. J. S. Neill and D. F. Babcock. The Dissipation of Reactor Heat at the Savannah River Plant. USAEC Report DP-1274, E. I. du Pont de Nemours and Co., Savannah River Laboratory, Aiken, SC (1971).

\section{ACKNOWLEDGMENT}

The efforts of J. E. Suich in preparing the computer programs to display the data are gratefully acknowledged. 
TABLE 1

Areas and Locations of Ponds at SRP

Pond

Nromber

$\frac{\text { SRP Grid Coordinates Area, }}{\text { East }}$

2

3

4

5

6 (Steed's Pond)

7

8 (Pond A)

9 (Pond 1)

10 (Pond 2)

116100

70400

60000

$\begin{array}{ll}114700 & 60390 \\ 93100 & 60000\end{array}$

62560

84740

51220

67900

78000

69500

69600

94500

71000

59300

52000

53000

2.5

2.5

2.4

4.4

1.6

11.2

2.0

6.4

0.4

19.6

$\begin{array}{llll}11 & 66200 & 62700 & 0.8 \\ 12 & 49000 & 51300 & 7.1 \\ 13 & 66800 & 22300 & 0.8 \\ 14 & 21000 & 48200 & 2.3 \\ 15 & 16400 & 45700 & 0.5 \\ 16 & 30000 & 31860 & 0.9 \\ 17 & 31500 & 24500 & 2.5 \\ 18 \text { (Pond B) } & 31800 & 16700 & 16.8 \\ 19 \text { (Pond C) } & 88000 & 57000 & 202.8 \\ 20 & 84000 & 50000 & 132.4 \\ 21 \text { (Par Pond) } & 85000 & 40000 & 2500.00^{*} \\ 22 \text { (Pond 4) } & 76700 & 50100 & 35.3 \\ 23 \text { (Pond 5) } & 78000 & 50000 & 9.9 \\ 24 & 42200 & 56800 & 1.2 \\ 25 & 48800 & 85280 & 1.2 \\ 26 & 58100 & 66700 & 0.8 \\ 27 & 18100 & 83000 & 5.4 \\ 28 & 36300 & 90160 & 0.8\end{array}$

With Par Pond: Mean Area 102.7 acres

$$
\text { Range } \quad 0.4 \text { to } 2500 \text { acres }
$$

Without Par Pond: Mean Area 17.6 acres

Range $\quad 0.4$ to 202.8 acres

* As given in Reference 4, not measured in this study. 
TABLE 2

Areas and Locations of Carolina Bays at the Savannah River Plant

\begin{tabular}{|c|c|c|c|}
\hline $\begin{array}{l}\text { Bay } \\
\text { Number }\end{array}$ & $\frac{\text { SRP Grid }}{\text { East }}$ & $\frac{\text { Coordinates }}{\text { North }}$ & $\begin{array}{l}\text { Area } \\
\text { acres }\end{array}$ \\
\hline 1 & 61000 & 98500 & 3.7 \\
\hline $2 * *$ & 62000 & 99000 & 9.3 \\
\hline 3 & 64000 & 93000 & 14.0 \\
\hline 4 & 64000 & 96500 & 3.2 \\
\hline 5 & 33000 & 103000 & 2.4 \\
\hline 6 & 33000 & 101500 & 11.2 \\
\hline $7 * \star$ & 32500 & 96000 & 6.2 \\
\hline $8 * *$ & 34500 & 96500 & 2.5 \\
\hline 9 & 35000 & 97000 & 4.3 \\
\hline 10 & 35500 & 97500 & 0.3 \\
\hline 11 & 36500 & 98000 & 1.9 \\
\hline $12 * \star$ & 36500 & 96000 & 1.9 \\
\hline $13^{* *}$ & 37000 & 95000 & 2.5 \\
\hline 14 & 36000 & 94500 & 3.7 \\
\hline 15 & 35500 & 95000 & 2.5 \\
\hline 16 & 35000 & 95000 & 5.0 \\
\hline $17 * *$ & 36500 & 104500 & 3.7 \\
\hline $18^{* *}$ & 30000 & 90000 & $<0.3$ \\
\hline $19^{* *}$ & 29500 & 89500 & 0.3 \\
\hline 20 ** & 28500 & 90500 & 3.7 \\
\hline $21^{* *}$ & 27000 & 89500 & 1.9 \\
\hline $22 \star \star$ & 26000 & 90000 & $<0.3$ \\
\hline 23 & 25500 & 89000 & 3.7 \\
\hline 24 & 26500 & 88500 & 1.6 \\
\hline 25 & 28500 & 84500 & 2.5 \\
\hline 26 & 26500 & 81500 & 1.2 \\
\hline 27 & 27000 & 81500 & 1.9 \\
\hline 28 & 47000 & 101500 & 5.0 \\
\hline 29 & 48000 & 102000 & 0.3 \\
\hline 30 & 61000 & 84500 & 1.9 \\
\hline 31 & 29000 & 80000 & 12.4 \\
\hline $32 * *$ & 71000 & 76000 & 9.3 \\
\hline $33 \star *$ & 73000 & 76000 & 12.4 \\
\hline $34 * *$ & 78000 & 68000 & 4.3 \\
\hline 35 & 72000 & 65000 & 3.1 \\
\hline 36 ** & 73500 & 62000 & 3.1 \\
\hline $37 * *$ & 71500 & 62000 & 2.5 \\
\hline $38^{* *}$ & 71000 & 63500 & 20.5 \\
\hline $39 * *$ & 69000 & 59000 & 1.2 \\
\hline 40 & 67000 & 60000 & 13.0 \\
\hline
\end{tabular}




\section{TABLE 2 (Cont'd)}

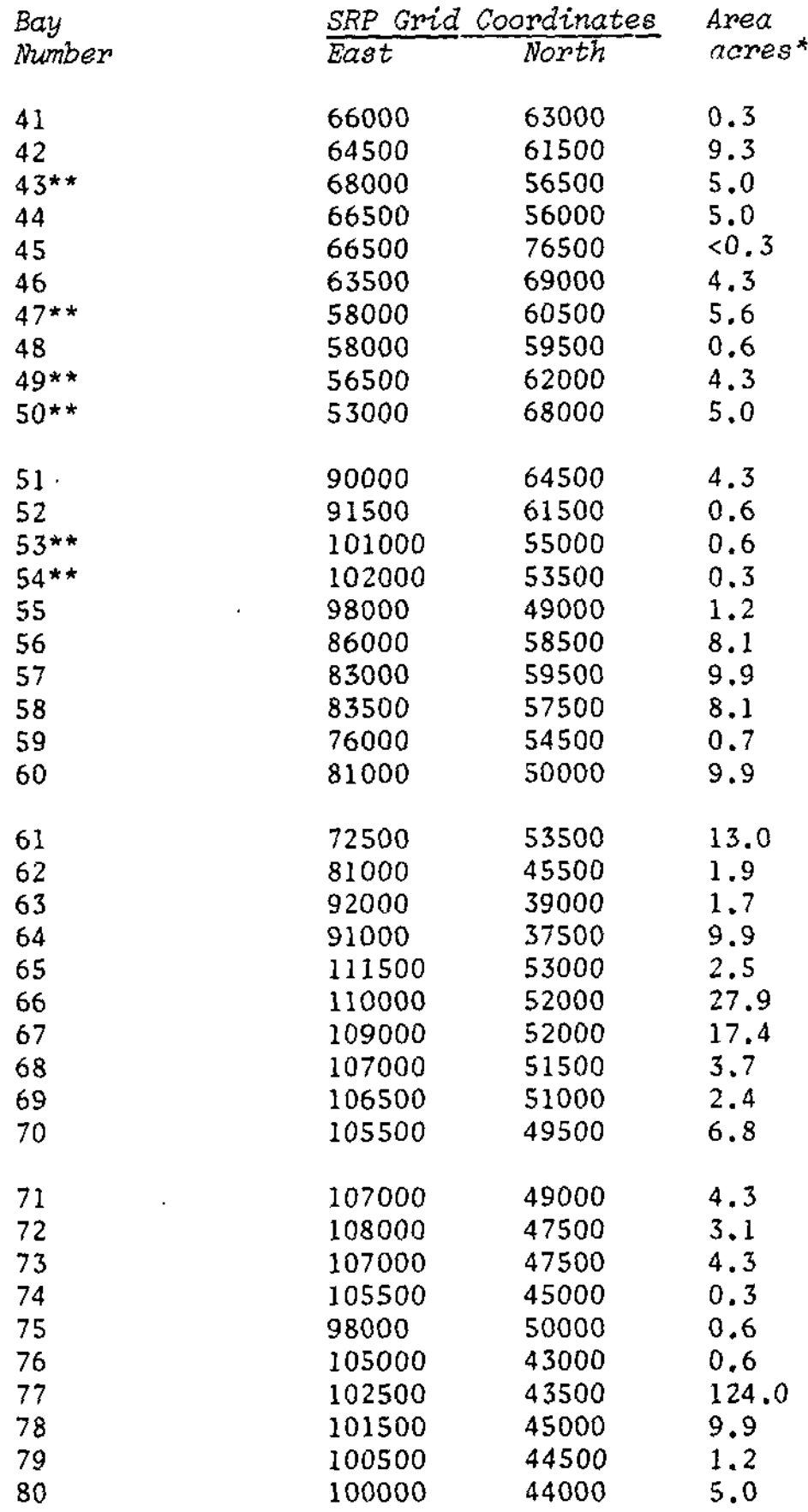


TABLE 2 (Cont'd)

Bay

Number

81

82

83

84

85

86

87

88

$89^{* *}$

90

91

92

93 **

94

95

96

$97^{*}$ *

98

$99^{* *}$

$100 * *$

101

$102 * *$

$103^{* *}$

104 **

105

106

107

108 **

109 **

110

111

112

$113^{* *}$

114

$115^{* *}$

116

117 **

118

119 **

120
SRP Grid Coordinates

East North.

95500

93500

88000

80000

73000

78500

80000

74500

71500

70000

68500

68500

67500

66500

67000

66000

66000

68000

62000

63500

62000

60000

58500

54000

56000

53000

56000

66000

$66001 \%$

64500

61000

61500

59000

61500

62000

57000

61500

57000

61000

53000
28500

27500

28000

41000

40500

38000

33000

38000

40500

39000

37000

32000

32000

28500

19000

17000

14000

49500

48500

46000

47500

47500

47000

44000

47000

46000

41000

39000

42000

35500

39500
38000
29500
39000
43000
33000
26000
29500
33000
31500

Area,

acres*

9.3

1.9

10.9

5.0

8.1

2.5

4.3

1.9

1. 2

2,5

1.9

3.1

8.1

2.5

1.2

91.1

79.4

104.9

3.7

0.6

1.2

2.5

4.3

6.8

5.6

6.2

5.0

3.1

7.4

1.9

0.3

0.3

3.1

1.2

9.9

1. 2

1.2

2.5

1. 3

1.9 
TABLE 2 (Cont'd)

\begin{tabular}{|c|c|c|c|}
\hline Bay & $S R P G r i$ & ordinates & Area, \\
\hline Number & $\overline{E a s t}$ & North & \\
\hline 121 & 55000 & 57000 & 3.7 \\
\hline 122 & 53500 & 61500 & 5.6 \\
\hline 123 & 48500 & 64500 & 1.9 \\
\hline 124 & 47000 & 61500 & 3.5 \\
\hline 125 & 48000 & 61500 & 5.0 \\
\hline 126 & 49000 & 61000 & 0.6 \\
\hline 127 & 48000 & 59000 & 8.7 \\
\hline $128 * *$ & 49000 & 58500 & 5.0 \\
\hline 129 & 51000 & 58000 & 1.2 \\
\hline 130 & 46500 & 58000 & 6.8 \\
\hline 131 & 49500 & 58000 & 2.5 \\
\hline 132 & 45000 & 53500 & 7.4 \\
\hline $133^{\star *}$ & 39000 & 43000 & 3.7 \\
\hline 134 & 38000 & 42500 & 1.2 \\
\hline 135 & 36000 & 43000 & 2.5 \\
\hline 136 & 31500 & 40500 & 1.8 \\
\hline $137^{* *}$ & 29500 & 38000 & 1.8 \\
\hline 138 & 31500 & 37500 & 1.9 \\
\hline 139 & 31500 & 36500 & 1.2 \\
\hline $140^{* *}$ & 33500 & 35500 & 3.7 \\
\hline 141 & 33500 & 35000 & 1.0 \\
\hline 142 & 35000 & 33000 & 14.3 \\
\hline $143^{* *}$ & 32500 & 28000 & 1.2 \\
\hline $144^{* *}$ & 45000 & 23000 & 1.9 \\
\hline $145^{\star *}$ & 45000 & 21500 & 3.1 \\
\hline $146^{* *}$ & 45000 & 20000 & 1.9 \\
\hline 147 & 37000 & 22500 & 5.0 \\
\hline 148 & 32500 & 20000 & 0.3 \\
\hline 149 & 33000 & 19500 & 1.2 \\
\hline 150 & 35000 & 18500 & 0.3 \\
\hline 151 & 30500 & 18000 & 0.3 \\
\hline $152^{\star *}$ & 26000 & 40000 & 3.7 \\
\hline $153^{* *}$ & 25000 & 41500 & 2.5 \\
\hline $154^{* *}$ & 24500 & 41500 & 1.9 \\
\hline $155^{* *}$ & 24000 & 41000 & 5.0 \\
\hline 156 & 30000 & 44500 & 1.9 \\
\hline 157 & 29000 & 44000 & $<0.3$ \\
\hline 158 & 29000 & 44500 & $<0.3$ \\
\hline 159 & 29000 & 45000 & $<0.3$ \\
\hline $160^{* *}$ & 28000 & 45000 & 1.2 \\
\hline
\end{tabular}


TABLE 2 (Cont'd)

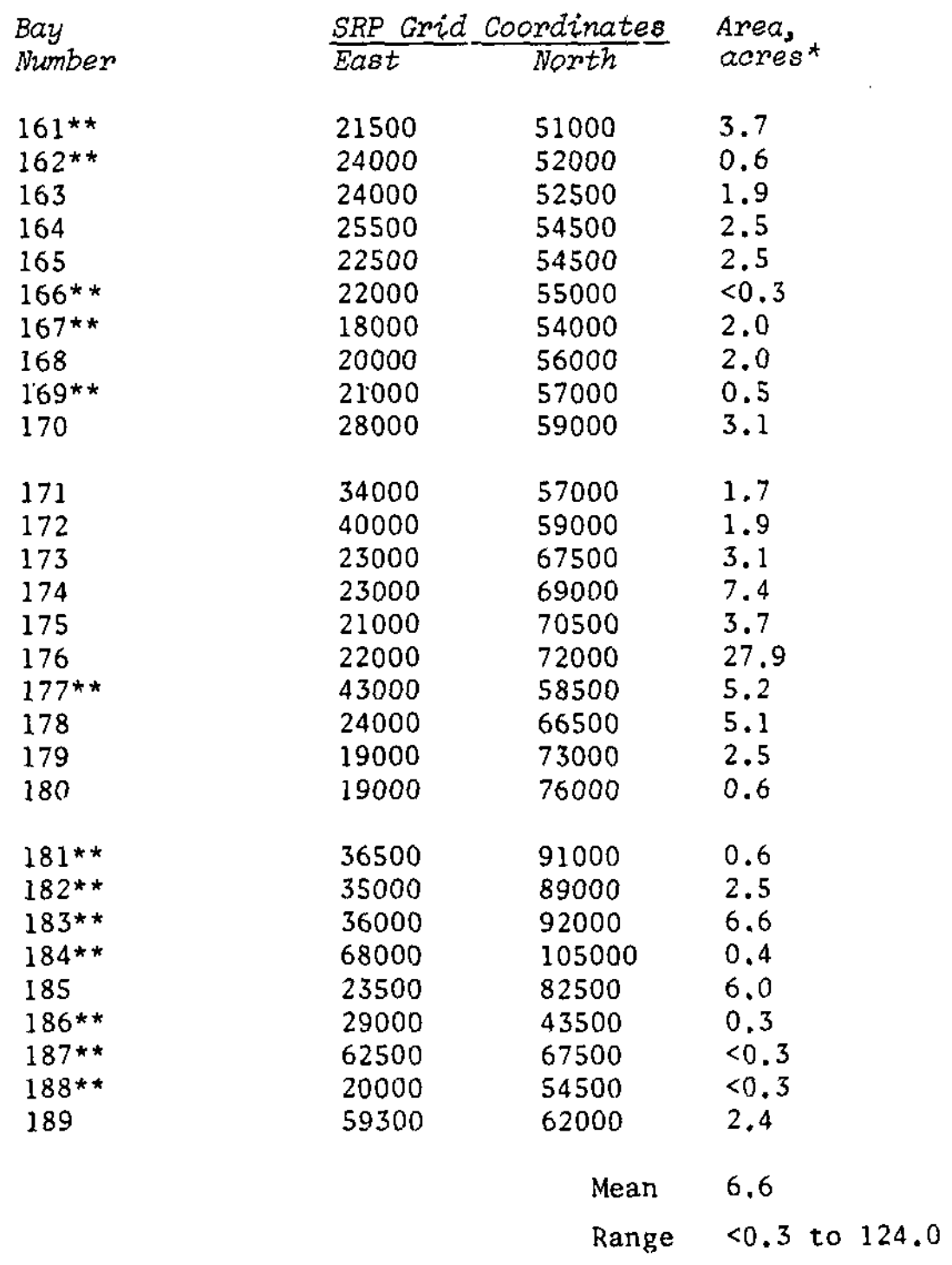

* The smallest measurable area with the planimeter was 0.3 acre.

* * Suspected bays. 


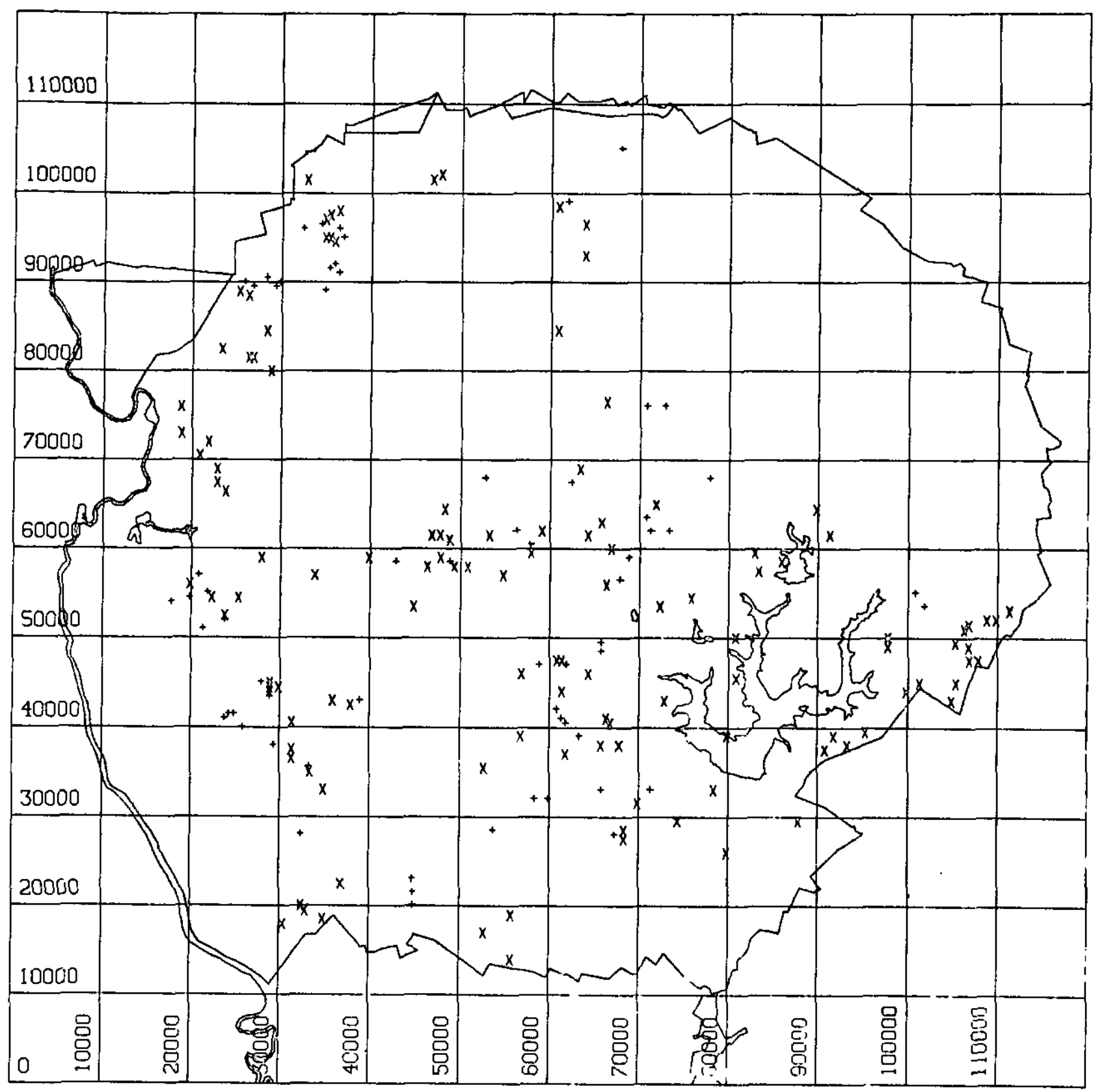

\footnotetext{
$x=$ known or

probable bay

$+=$ suspected bay
}

FIGURE 1. Carolina Bays on the Savannah River Plant Reservation 


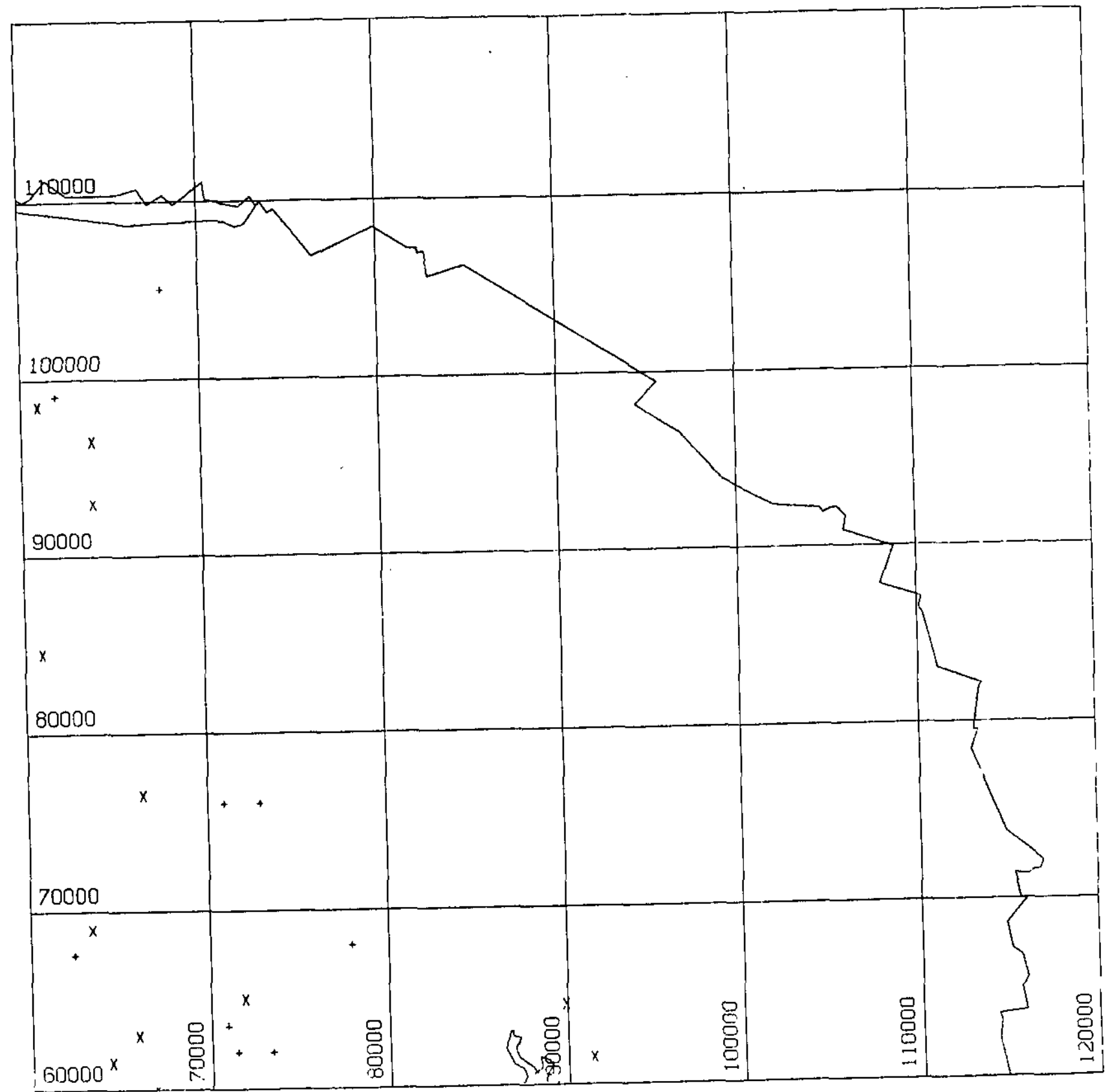

$$
\begin{aligned}
& X=\begin{array}{l}
\text { known or } \\
\text { probable bay }
\end{array} \\
& +=\text { suspected bay }
\end{aligned}
$$

FIGURE 2. Carolina Bays on the Northeast Quadrant of the Savannah River Plant Reservation 


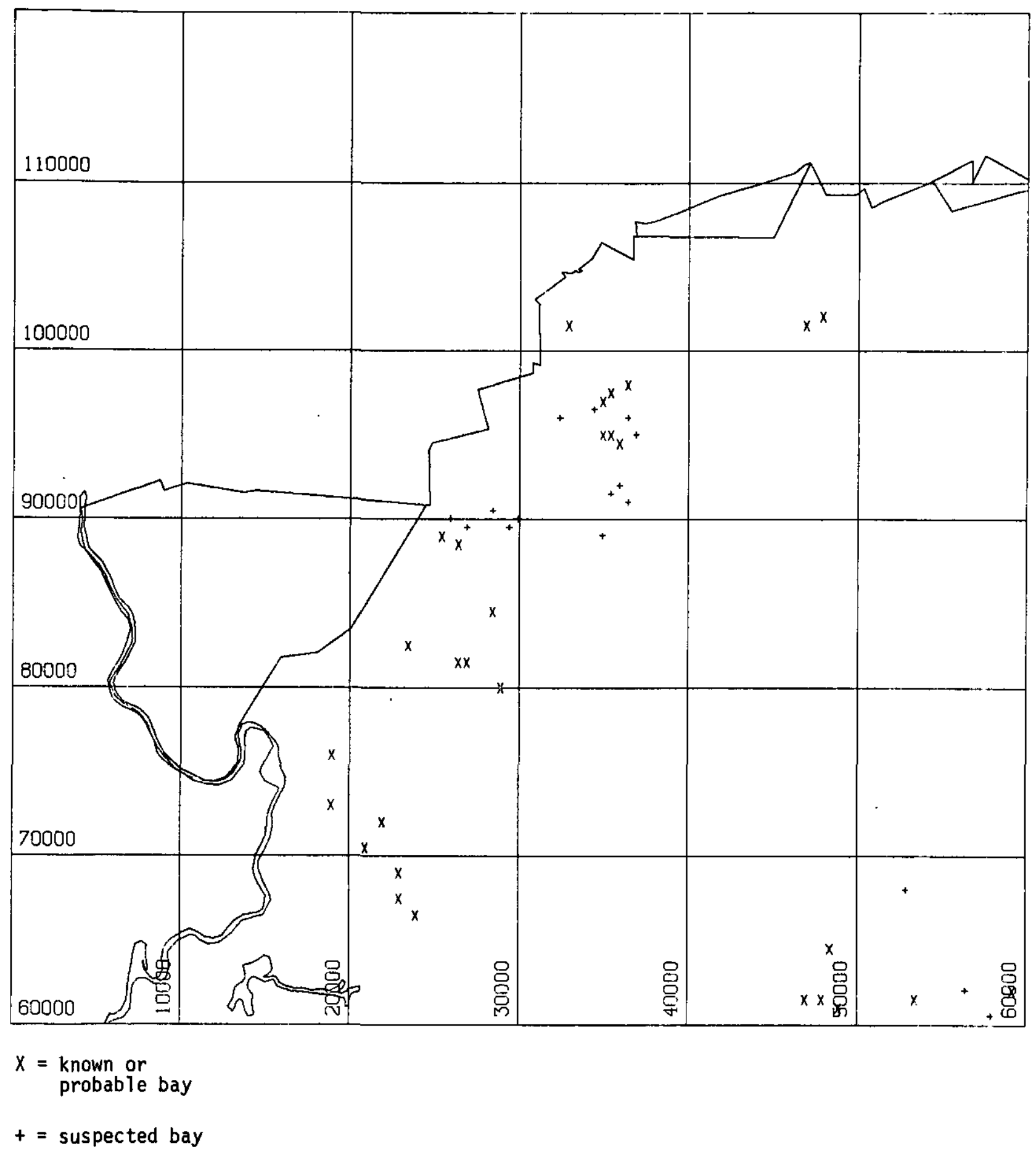

FIGURE 3. Carolina Bays on the Northwest Quadrant of the Savannah River Plant Reservation 


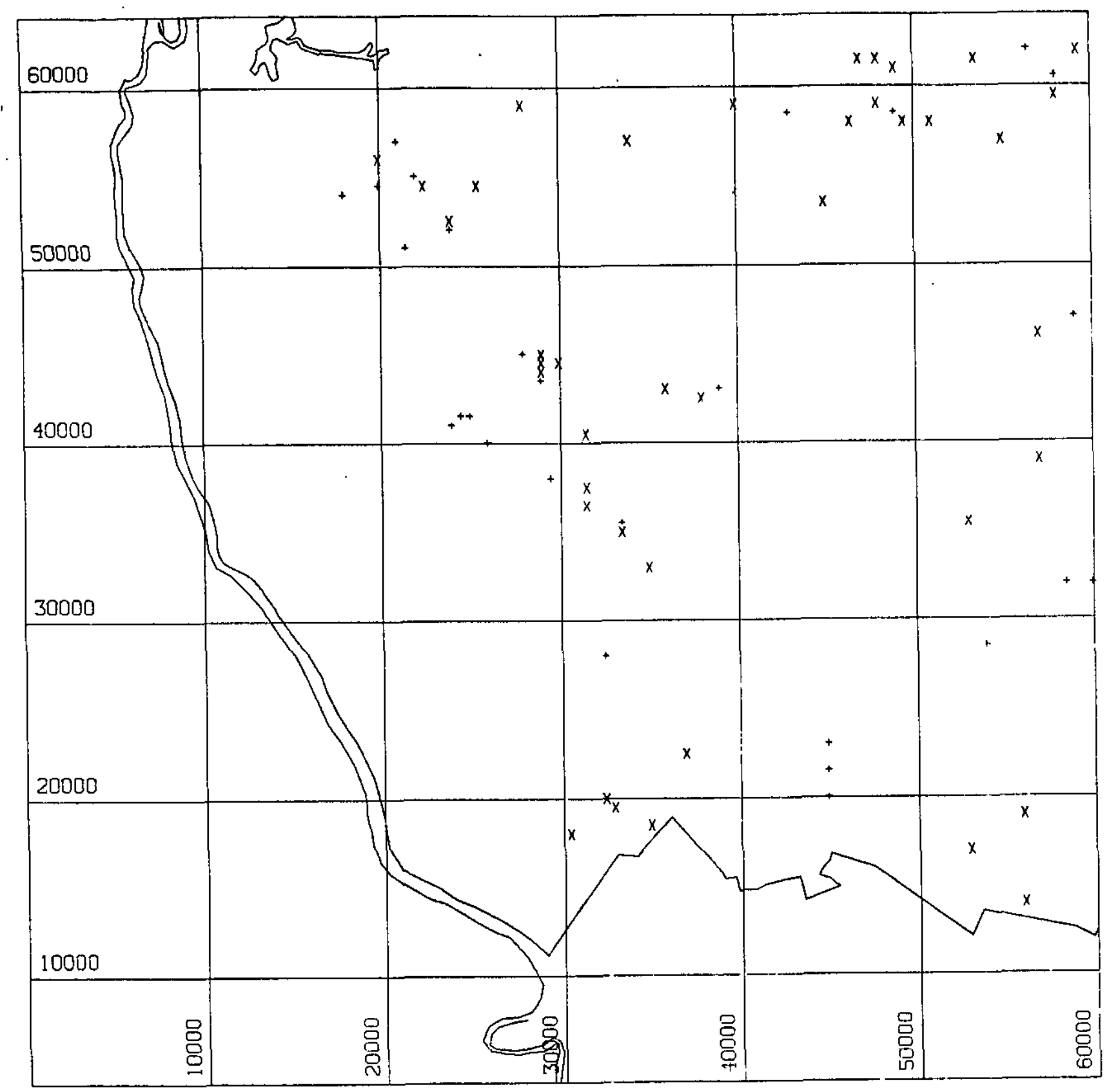

$$
\begin{aligned}
& X=\begin{array}{l}
\text { known or } \\
\text { probable bay }
\end{array} \\
& +=\text { suspected bay }
\end{aligned}
$$

FIGURE 4. Carolina Bays on the Southwest Quadrant of the Savannah River Plant Reservation 


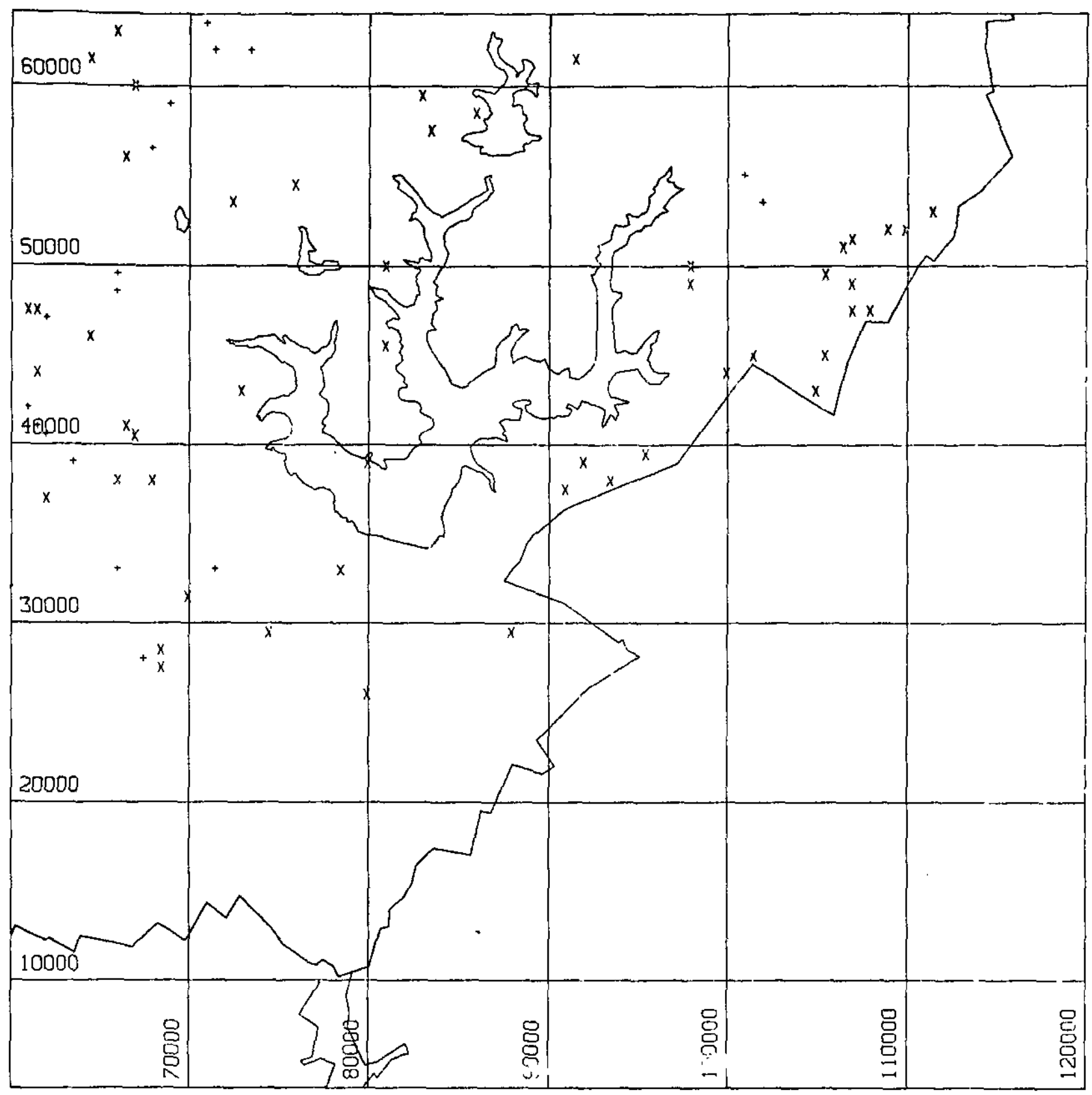

\section{$x=$ known or \\ probable bay \\ $+=$ suspected bay}

FIGURE 5. Carolina Bays on the Southeast Quadrant of the Savannah River Plant Reservation 


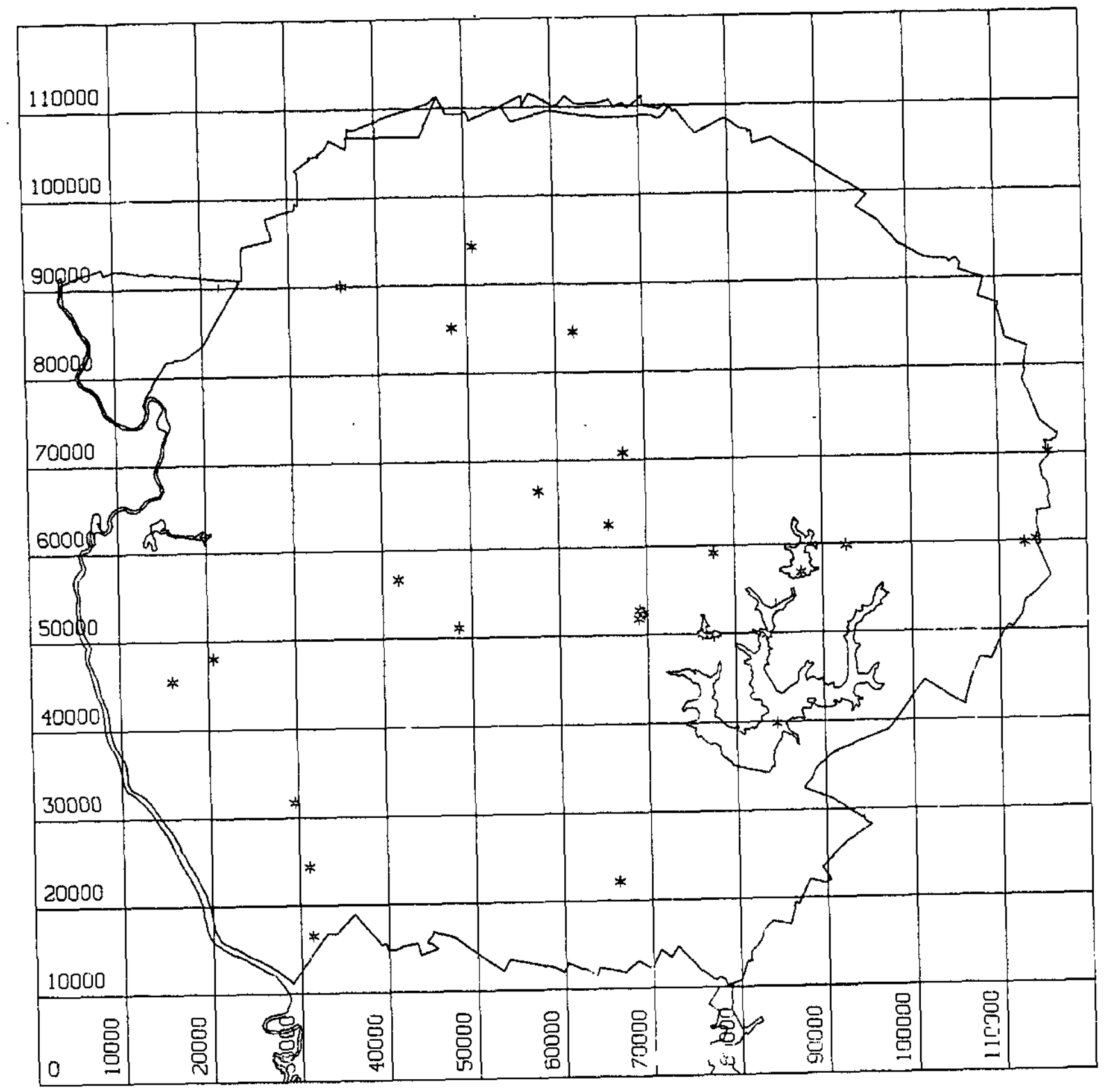

FIGURE 6. Ponds on the Savannah River Plant Reservation 


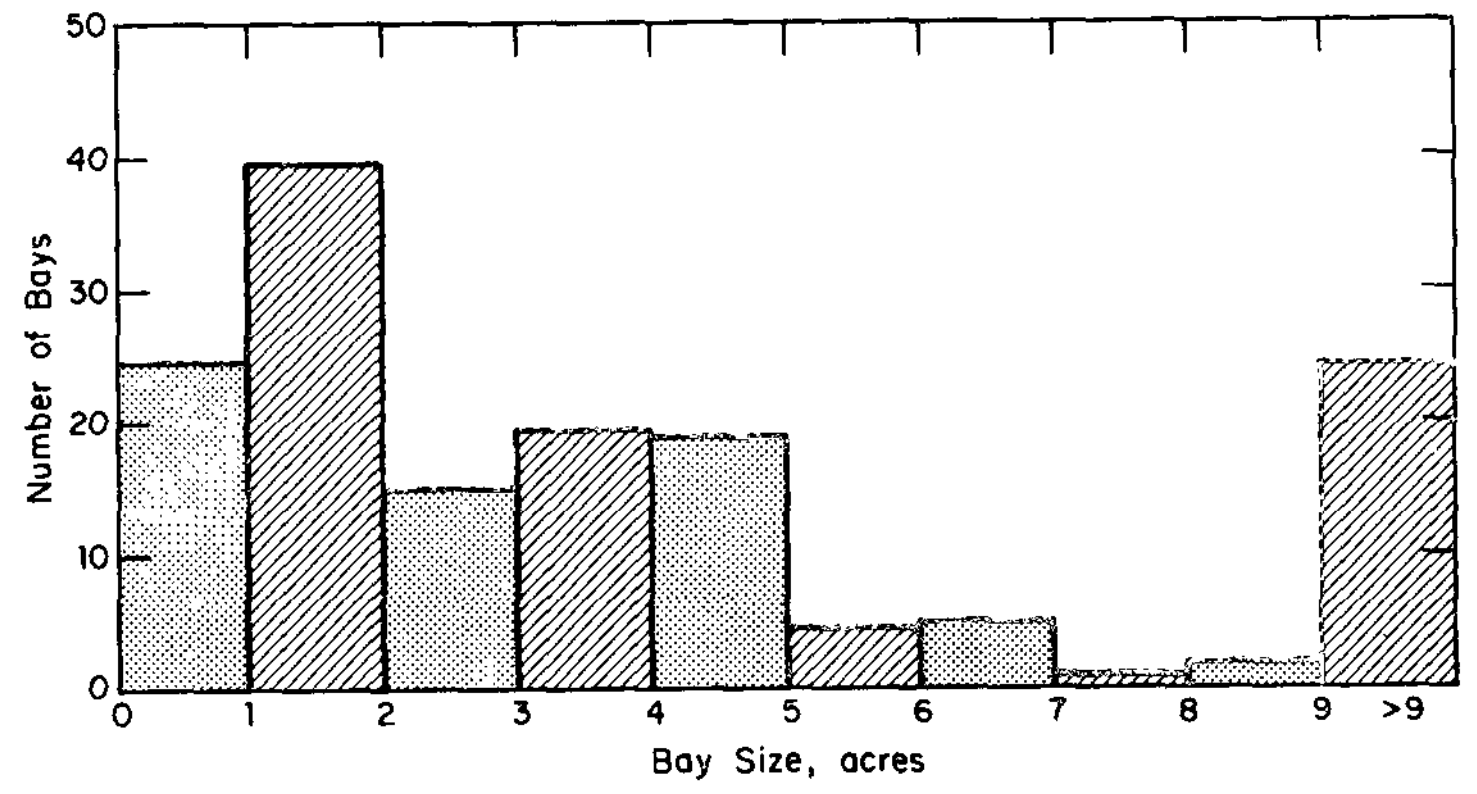

FIGURE 7. Size Distribution of Carolina Bays at SRP 